\title{
'Let Lovers Sigh Out the Rest': Witnessing the Breath in the Early Modern Emotional Body
}

\author{
Naya Tsentourou
}

To argue that the breathing body is an emotional body runs the tautological risk of attempting to define the shared, universal experience of breathing with the shared, universal experience of feeling. After all, we breathe, ergo we feel. Or is it that we feel, thus we breathe? Except for cases of mechanical ventilation supporting bodies beyond the capacity of emotional or other communication, breath and emotions are vital in how we engage with the world around us and with each other. Everyday discussions of breath and emotions in restorative contexts, such as medicine and yoga, centre around the rhetoric of inside/out as in calls to take a deep breath and 'let it flow out gently' in order to negotiate negative feelings like stress, anxiety, and panic. ${ }^{1}$ Breath is essential to wellbeing as it can effect relaxation: "with a bit of practice changing how you breathe can make a real difference to how you feel'. 2 The onus in such

N. Tsentourou $(\bowtie)$

University of Exeter, Exeter, UK

(C) The Author(s) 2021

D. Fuller et al. (eds.), The Life of Breath in Literature, Culture

and Medicine, Palgrave Studies in Literature, Science and Medicine, https://doi.org/10.1007/978-3-030-74443-4_9 
contexts falls on the patient's breathing body to help alleviate the symptoms of the emotional body and reinstate the patient as a physically and emotionally regulated being. The rhetoric of these therapeutic guidelines therefore serves to produce two bodies: the one in need and the one in agency. This essay is concerned with the history of this division and its implications for current perspectives on the 'usefulness' of breath in articulating and managing emotions. Focusing on instances of breathing and suffering in cases of love melancholy in early modern literary and medical texts, I seek to complicate the notion that breath helps us manage feelings by arguing instead that breath itself is a feeling that registers the emotional displacement of the self, rather than serving as the self's founding principle. The essay concludes by showing how displaced breath points to the body's emotional entanglement with its surroundings and its observers, an entanglement that confuses the patient and physician binary.

Versions of a displaced self are common in seventeenth-century religious poetry where the speaker often tries to reconcile his or her current fallen and ignorant state with the promise of divine grace and fulfilment. George Herbert's 'Love Unknown' is, as the title suggests, a poem about the speaker's inability to understand God's love, presented to him in three quasi-allegorical episodes where the speaker's heart is acted upon via water, fire, and thorns. Published in the 1633 collection, The Temple, the poem charts a tale 'long and sad' (1. 1) that allows the speaker to dwell in the pain of his encounter with the servant, a proxy for God, who patiently educates him into understanding that it is the heart's renewal that God seeks, not the works and rituals professed to accomplish that. ${ }^{3}$ The narrative is divided into four sections: the first three list the steps the speaker takes to approach God and how these are corrected by the servant. The ceremonial, almost detached, offering of the heart on a plate of fruit is interrupted by the servant seizing the heart and throwing it in a font to be washed and violently wrung (1. 17). Next, the speaker's sacrifice from the heart turns into a sacrifice of the heart when the servant intervenes again to throw the heart 'into the scalding pan' (1. 35). Finally, returning to his bed and the comfort of insipid formal worship, the speaker finds that the servant/God disrupts the temporary solace with painful, yet productive, moments of self-reflection in the shape of thorns (1. 52). The fourth section is spoken in the voice of the interlocutor and spells out the lessons learnt in the three episodes. The overall message of the poem seems to be that 'God does not work upon man to get him to do certain things but to get him to be a certain way $[\ldots]$ in a state, that is, of complete 
and total responsiveness'. ${ }^{4}$ While, as Strier argues, the 'aim and mark of the whole discourse is joy', the dominant emotion that shapes the speaker's responses to the events is pain. ${ }^{5}$ Pain is captured and reimagined in embodied terms such as 'the very wringing yet / Enforceth tears' (11. 1718), or in paratextual cues, such as the capitalization of AFFLICTION (1. 28), pointing to the 'predisposed melancholy' that permeates Herbert's verse. ${ }^{6}$ Melancholic pain interjects in the poem, and in the overall experience of coming to know God's 'love unknown', with dysregulated, aching breaths at key moments in the devotional situation. The three episodes of correction follow a parallel format: the speaker is under the impression he is performing his religious duties right or is enjoying momentary relief after the servant's intervention, only to walk into his next disorienting trial.

To him I brought a dish of fruit one day, And in the middle plac'd my heart, But he

(I sigh to say)

Lookt on a servant, who did know his eye

Better then you know me, or (which is one)

Then I my self. The servant instantly

Quitting the fruit, seiz'd on my heart alone. (11. 6-12)

But you shall hear. After my heart was well, And clean and fair, as I one even-tide

(I sigh to tell)

Walkt by my self abroad, I saw a large

And spacious fornace flaming, and thereon

A boyling caldron, round about those verge

Was in great letters set AFFLICTION. (11. 22-28)

... I hasted to my bed.

But when I thought to sleep out all these faults

(I sigh to speak)

I found that some had stuff'd the bed with thoughts,

I would say thorns. Deare, could my heart not break,

When with my pleasures ev'n my rest was gone? (1l. 48-53)

While the transitions demarcate the speaker's gradual awakening to the centrality and intimacy of the heart, the reader cannot but notice the visual effect of the lines. If, in Herbert's poetry, 'words are to be seen as 
well as heard, and the shape of a poem on the page can contribute significantly to its meaning', what the reader sees each time connecting the two emotional extremes - temporal complacency and painful encounter-are the bracketed exhalations: '(I sigh to say)', '(I sigh to tell)', and '(I sigh to speak)'. 7 To 'say', to 'tell', to 'speak' of pain is not enough without theliterally and metaphorically-side-lined breath that makes it all possible. Breath becomes materially grafted on the text as interruption, a bracketed interjection that visualizes a new model of readerly engagement: by pausing the narrative to take a bracketed breath, the text turns the reader into the friend present in the speaker's account. In these aside moments the poet momentarily abandons his role of 'an empiricist conducting research', witnessing the suffering body from a privileged, external point of view, and we come to see and hear the exhalations in real time. ${ }^{8}$ The displaced heart at the emotional centre of Herbert's poem co-exists with and manifests itself in the displaced breath. Moreover, the displaced sighs become a threshold where the speaker meets the divine and meets the reader as well, encountering the other in a space simultaneously inside and outside discourse. Christian love is about the suffering body but, in its tormented breathing, that body is not passively reflecting an emotional state. Via its exhalations, it connects to the world.

Even though the 'emotional turn' in early modern studies has so far completely bypassed Herbert, his poetry not only speaks to the field's pursuit of particularizing emotions in their cultural and historical milieu (especially in relation to seventeenth-century theological and literary contexts), but, as is evident in the example of 'Love Unknown', it has the potential to expand this pursuit to include considerations of the breath, especially in relation to the study of melancholy. ${ }^{9}$ The study of the history of emotions has found ample ground in the early modern period's blend of humoral medicine with emerging discourses of embodied subjectivity, whether these relate to religion, theatre, material culture, or environment. ${ }^{10}$ While the body's humours have been exhaustively revisited and documented either in favour of or against Galenic models of selfhood, and while blood has been the subject of multiple publications and scholarly interest, the body's pneumatic consistence has been less well-recognized, to the point where we can extend to historians of emotion Irigaray's accusation of Heidegger, of forgetting the air. ${ }^{11}$ Discussions dedicated explicitly to early modern breathing are sparse, and tend to examine breath alongside humoralist macro-micro analogies and conventional (i.e., Galenic) medical frameworks that pathologize the 
body. ${ }^{12}$ Breath and air often become indistinguishable in such analyses, and understandably so. Herbert, however, in trying to formulate divinehuman love, does not refer to the air; he refers to the breath. This is a breath that is not just released in pain but does something to the text and to the world outside that text, in communicating love as displacement.

The performative displacement of the self in love that we encounter in Herbert was a common feature of early modern medical literature on the passions. ${ }^{13}$ Like the friend in 'Love Unknown' who diagnoses the speaker's condition and explains the moral lesson, medical writers recorded their observations of lovesickness by turning the patient's breathing, among other symptoms, into an object for study. The remainder of this essay engages directly with references to the respiration of the melancholic lover in these publications to establish how the breath is seen to choreograph the responses of the body in a way that distances it socially and (inter)textually. ${ }^{14}$

Robert Burton's magnum opus, The Anatomy of Melancholy (1620), lists the symptoms of love melancholy with the air of detached and disinterested observation that characterizes the majority of the citations employed so profusely in this dizzyingly encyclopaedic work:

Symptomes are either of Body or Mind; of body, palenesse, leannesse, drinesse, \&c. ${ }^{a}$ Pallidus omnis amans, color hic est aptus amanti, as the Poet describes lovers: fecit amor maciem, Love causeth leannesse. ${ }^{\mathrm{b}}$ Avicenna de Ilishi cap. 23. makes hollow eyes, drinesse, Symptomes of this disease, to goe smiling to themselves, or acting, as if they saw or heard some delectable object. Valleriola lib. 2. observat. cap. 7. Laurentius cap. 10. Alianus Montaltus de Her. amore. Langius epist. 24. lib. 1. epist. med. deliver as much, corpus exangue pallet, corpus gracile, oculi cavi, leane, pale, ut nudis qui pressit calcibus anguem, hollow-eyed, their eyes are hidden in their heads, ${ }^{\mathrm{c}}$ Tenerque nitidi corporis cecidit decor, they pine away, and looke ill with waking, cares, sighes, Et qui tenebant signa Phrebea facis / Oculi, nibil gentile nec patrium micant. With groanes, griefe, sadnesse, dulnesse,

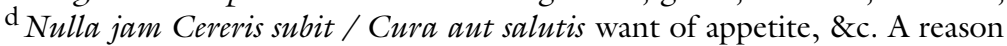
of all this, ${ }^{\mathrm{e}}$ Jason Pratensis gives, because of the distraction of the spirits the Liver doth not performe his part, nor turnes the aliment into bloud as it ought, and for that cause the members are weake for want of sustenance, they are leane and pine, as the hearbs in my garden doe this month of May, for want of raine. ${ }^{15}$ 
The body in love is a body left to waste, as its complexion and basic functions, like breathing, eating, and digesting food, are suspended as a result of distraction by the love object. The symptoms of love melancholy entail a paradoxical performance of embodied yet at the same time 'antibodied' gestures. Leanness, paleness, dryness, hollow eyes, and sighs are defined by what they are not: not enough fat, blood or moisture, eyes that look but do not see, sighs instead of regular breaths. In the tradition of melancholy writings sighing is evidence of an overheated, overemotional heart, as well as the body's natural way of restoring balance by cooling the heart through larger than normal inhalations. Sighs and sobs, as Timothy Bright writes, respond to the heart's 'greater necessity of breathing, which being not answered through imbecility of the breathing parts, discharges the office of respiration by sobbes, which should be performed by one draught of breath'. 'Differing onely in that sobbes are sighinges interrupted, and sighes sobbes at large', excessive breathing is a response to the feebleness caused by melancholy. ${ }^{16}$

In the extract from the Anatomy Burton casually places sighing on the list of symptoms, but refrains from the clinical language of Bright; after all the subject of the third partition is love melancholy and, in his usual repetitive and relentless style, Burton has already catalogued medical opinion on the symptoms more extensively elsewhere (see 1 . 381-384, 'Symptomes, or Signs of Melancholy in the Body'). The third partition is instead taken up with numerous verses that interrupt the flow (if there is a flow) of the treatise to reference examples of lovers and their predicament. Section 2, Member 2, Subsection 4 is a case in point. The subject matter of this section centres around enticement and amorous exchange, covering voice, singing, kissing, dancing, promising, and weeping, as strategies lovers employ to fulfil their desires. Burton references a wide spectrum of mythical and literary tales to support his discussion, acknowledging their fictional status: 'These are tales you will say, but they have most significant Moralls, and doe well expresse those ordinary proceedings of doting Lovers' (3.118). Analysing the 'progresse of this burning lust', he invites the reader to 'observe but with me those amorous proceedings of Leander and Hero', before quoting the following passage in Latin and English:

With becks and nods he first beganne,

To try the wenches minde,

With becks and nods and smiles againe 
An answere he did finde.

And in the darke he tooke her by the hand, And wrung it hard, and sighed grievously, And kissed her too, and wo'd her as he might, With pitty me sweet heart or else I dye, And with such words and gestures as there past, He wonne his Mistris favour at the last. (3.117)

Leander's performance of courtship shares all the features Burton has been listing, such as becking, nodding, smiling, sighing, and kissing. The 'grievous sighing' is part of the vocabulary of the melancholic lover's diagnosis: 'And surely this Aphorisme is most true, If a lover be not jealous, angry, waspish, apt to fall out, sigh os sweare, he is no true lover' (Burton 3.119), a convention that reduces sighs to a trope famously embodied by Romeo in Shakespeare's Romeo and Juliet, as in this description by his father: 'Many a morning hath he there been seen / With tears augmenting the fresh morning's dew, / Adding to clouds more clouds with his deep sighs' (1.1.129-131). As the audience is invited to imagine a Romeo in isolation, releasing heavy breaths in response to his love, the Anatomy reader is asked to observe from a safe distance the unfolding of Leander's passion. The spatial exclusion of the melancholic lover is to a large extent self-imposed, the result of the body withdrawing and excluding itself from its everyday functions. The respiring lover appears to be constantly under observation as he chooses to place himself outside social circles. André Du Laurens's influential A Discourse of the Preservation of the Sight; of Melancholike Diseases; of Rheumes and of Old Age (published in French in 1597, and translated into English in 1599) presents to the reader the lover's extreme isolation in similar lines:

You shall finde him weeping, sobbing, sighing, and redoubling his sighes, and in continuall restlesnes, auoyding company, louing solitarines, the better to feed \& follow his foolish imaginations; feare buffeteth him on the one side, \& oftentimes dispayre on the other; he is (as Plantus sayth) there where indeede he is not. ${ }^{17}$

The distance in the lover's case renders sighing theatrical, and if not insincere, then a superficial indication of a superficial love. The act of witnessing from the physician's perspective the fantastical plight of the patient turns comical in the prefatory material of the 1640 translation of Jacques Ferrand's treatise, Of Lovesickness (1610). Edmund Chilmead's 
translation, titled Erotomania, is prefaced with a compilation of dedicatory verses addressed 'To the Author on his Love-Melancholy', playfully mocking the lover's appearance: ${ }^{18}$

Pray y' pitty him, Lady! How you make him looke!

His cloathes he weares, as if he had mistooke

One peice for t'other; and you may safely sweare,

Though he seeme drest, yet they still scatter'd are.

His buttons, (like Tarquins Poppy heads) fall down,

Some halfe a dozen at a sigh; and's Crowne

Is grown bald with scratching Tunes out. (Ferrand 1640, np)

The dishevelled image is accentuated by the constant sighing, which is imagined as requiring a double inhalation, stretching the chest, and thus the clothes of the lover, to the limit, undoing buttons with every breath. Sighing performatively discovers the body not only in the act of releasing air but in undressing it. It is one of the tricks the lover as actor puts on and which another poet dismisses as inauthentic:

You that still sigh, not breath; and fondly dote

On every Black-bagge, and new Petticoate.

Playing your sad and Melancholy tricks,

Like devout Iesuits 'fore a Crucifixe.

Being All things, but your selfe. (Ferrand 1640, np)

In Ferrand's own account, sighs are the result of forgetfulness. Forgetful, the melancholic body attempts to carve a space for itself that goes against its physiology as the lover is seen to interfere with the natural process.

Sighs come to melancholy lovers because they forget to breathe due to the absorbing fantasies they feed upon, whether in looking upon the beloved or in contemplating her absence, in meditating upon her winning qualities or in searching for the means to enjoy the desired object. Once the lack is realised, nature is constrained to draw in the quantity of air in a single gasp that is taken in normally in two or three breaths: that form of respiration is called a sigh, which is in fact a doubling of the breath. (Ferrand 1623, 280)

To be the melancholic lover means to be fully 'absorbed', to be so consumed by the passion that there is no more space for air to circulate in 
the heart. The beloved party has succeeded in literally pushing out from the lover's heart any other matter. Seeking to cool the heart's suffocating heat by inhaling more than usual, sighs are the body's attempt to dislocate the love object from the heart and to reinstate some air. The deep breath restores some equilibrium, but this balancing act inevitably privileges nature over imagination, body over mind. Nature is perceived to rescue the body that is threatened by the mind or soul's obsessive meandering. The duality is perplexing: sighing is a product both of nature and 'art' (in the sense of its being a staple of the lover's repertoire). What creates this division is perspective, and the observer's view. Burton, Du Laurens, and Ferrand as observers on the one hand invite the reader to single out the patient and diagnose his breathing as a theatrical tool of wilful displacement, and on the other undermine such conscious involvement on the part of the patient by describing sighing as a reflex. Unlike Herbert's poetic blend of pneumatic subjectivities of reader, speaker, and author, passionate breathing in writings on lovesickness imposes boundaries between author and subject of study, boundaries that appear to devalue or in the best case pathologize the experience of the emotion.

In trying to cordon off emotional breathing and relegate it from nature to art, however, the authors cannot escape the artifice of their supposedly objective, or scientific, discourse and the multiplicities inherent in it. For instance, Burton's Partition 3, Section 2, Member 2, Subsection 4 in its inclusion of 'tales' with 'most significant Moralls' is the most digressive section of the Anatomy, not only thematically, as it moves from one method of enticement and one love gesture to the next, but also structurally, as the flow is continuously interspersed with verses in Latin and English. The visual outcome is pages that look more like a selection of quotations of poetry, akin to a commonplace book, where the clinical and detached style of the voluminous treatise is abandoned for the heartfelt verses of Leander, Cleopatra, Venus, from poems by Theocritus and Apuleius among much else. By the time the sixth edition, 'corrected and augmented by the author', appears in 1651, the section is bursting with numerous other verses, including lines spoken by Orpheus, Dido, Euryalus, Phaedra, Myrrha, and Medea. Famous love stories from antiquity and up to the late medieval period, including Petrarch's pleas to Laura, are represented with passionate verses that bring emotion to the Anatomy's otherwise passionless project. If we accept that the Anatomy's textuality embodies the 'melancholy performativity' it seeks to record, and 
that Burton 'divorces citation from endorsement' 'to keep authority itself permanently in question', Partition 3, Section 2, Member 2, Subsection 4 is a prime example of how the medical veneer that keeps the melancholic lover at arm's length is interrupted and undercut by the voice of that lover. ${ }^{19}$ Seeing the verses as short vigorous outbursts in a dull scientific context, the section embodies in its fragmented textuality the palpitation of the heart and shortness of breath the writers associate with love melancholy. The Anatomy here executes what Burton instructed earlier, referring to love as madness in his prefatory epistle 'Democritus Junior to the Reader': 'I shall dilate this subject apart, in the meane time let Lovers sigh out the rest' (1.103). The lovers indeed take centre stage and make the point for and instead of the author. The emotion speaks from the margins, from intertextual references, that complicate the reader-author dynamic as they seek to immerse both in their indented reality. Despite their claim to scientific impartiality, early modern writings on melancholy like Burton's can be seen to operate on an emotional axis similar to Herbert's bracketed verses: letting in and expressing passionate love while cordoning it off as their subject matter.

A similar blend of intertextual emotionality infuses Ferrand's Chapter XIV on 'Diagnostic Signs of Love Melancholy' (Ferrand 1623, 269-73). Explaining how lovers 'sigh at frequent intervals and complain without reason', Ferrand follows his statement with a reference to Sappho who 'could no longer weave her cloth' (Ferrand 1623, 270). The rest of this section is dominated by the common link between the tale of Antiochus and Stratonice and Sappho's poetry, the embodied symptoms of love melancholy. 'The verses of the learned and amorous poet Sappho' are cited in Greek, Latin, and French translations, with the latter being the most extensive (Ferrand 1623, 271). As in the Anatomy, the description of lovesickness requires the medical narrative to be interrupted by verses of love. ${ }^{20}$ The lover's fragmented speech and inability to breathe regularly are reflected in the text's disjointed appearance. The rendition of the passionate inarticulacy that accompanies love in multiple different languages and words mirrors the 'babbling that comes from the surfeit of the heart' (Ferrand 1623, 270). It is as if Ferrand cannot help indulging in Sappho's poetry of the ineffable. 'Speechless', 'my tongue falters', 'my tongue becomes heavy', this is Sappho, but also Ferrand in love with Sappho. Ending the poetic infusion with a rhetorical question, Ferrand revels in the poet's subjective telling of the classical physician's objective 
knowledge: 'Does it not appear that Sappho was as wise and as experienced in this art as our Greek, Latin, and Arab physicians in light of the fact that they mentioned no indisputable signs that this lady did not already know?' (Ferrand 1623, 272). Although the revised treatise is considered to be 'more sober and vigilant, more disciplined by the procedures of the scholastic medical treatise' compared to the 1610 edition, in moments like this, Sappho, Ferrand, and the lover blend into one, retaining the Ovidian elements of the first treatise (Ferrand 1623, 23). Approximating Burton's philosophical and literary style, Chapter XIV challenges the perceived differences between the 1610 readership of 'the lovers themselves, captivated by the beauty of their ladies' and the 1623 audience of 'the medical profession concerning these lovers' (Ferrand $1623,23)$.

Unruly emotion does not only produce the self-unravelling breaths that are sighs but also affects pulse fluctuation. The most famous example is the story of Antiochus and Stratonice, which remained popular in the Western literary and medical imagination from its early versions in Valerius Maximus and Plutarch to its re-imagining by Petrarch, right through the time these treatises of passions were produced and beyond. ${ }^{21}$ It is a tale that depicts the extreme physical ailment of unrequited love and the dangers of lovesickness, while it celebrates the unconditional love of a father for his son. Burton, Du Laurens, and Ferrand all engage with the story. Du Laurens summarizes the tale:

By all these tokens the great Phisitian Erasistratus perceiued the disease of Antiochus the sonne of Seleucus the king, who was readie to dye for the loue of Stratonica his mother in law. For seeing him to blush, to waxe pale, to double his sighes, and change his pulse so oft at the very sight of Stratonica, he deemed him to bee troubled with this eroticke passion; and so advertised his father. ${ }^{22}$

Erasistratus relates his diagnosis to King Seleucus who in an act of selfsacrificial parental love hands his wife Stratonice to his son. From a medical point of view the story is evidence of how intensity of feeling accelerates the pulse and how this symptom is a safe indicator of an internal passionate condition. Antiochus, who in most versions of the story is said to have been so desperate that he decided to perish by refusing to eat, has his body and his secret betrayed by his pulse as it is read by the physician without his knowledge and consent. Erasistratus 
in this case might not have been acting only as the king's physician, but might have had a personal interest in experimenting with a lover's pulse; he has been credited with discovering the role of the diaphragm in breathing, and belongs to the group of Hellenistic philosophers interested in determining how respiration worked and the role of blood and pneuma in the human body. ${ }^{23}$ The presence of the lover was necessary to throw the pulse off its regular rhythm. Burton cites another physician, Josephus Struthlus, who speaks of 'this particular love pulse', and determines the object of his patient's love just by naming him: 'hee named many persons, but at the last when he named him whom he suspected, her pulse began to varie and to beat swifter, and so by often feeling her pulse, he perceiued what the matter was' (Burton 3.142-143). Ferrand goes even further and instead of reciting the tale of Antiochus and Stratonice, he records a version of it with himself as the protagonist. He includes an anecdote from 'May 1604, when I was just beginning my practice in Agen' (Ferrand 1623, 273). In the story, Ferrand 'diagnosed...the love madness of a young scholar' who, having fallen into despair and resorted to every physician and a mountebank in the city, cannot be cured (Ferrand $1623,273)$. Ferrand narrates how he observed his symptoms, and taking into account his scholarly profession, 'I concluded, for my own part, that he was lovesick' (Ferrand 1623, 273). As another Erasistratus, he succeeds in identifying the object of the scholar's love when 'an attractive girl of the house came in with a lamp as I was taking his pulse, which from that moment went through a series of changes' (Ferrand 1623, 273). The continuities with the classical tale do not end here: Ferrand is entreated by the scholar to negotiate the match with the maid despite his father's objections to his marrying someone from a lower class, since 'his life depended on' it (Ferrand 1623, 273). The scholar's father is no Seleucus, however; the match falls through and the scholar only survives following Ferrand's 'medical remedies', which appear much later in the book and are unknown to the reader at this stage (Ferrand 1623, 273). The tale of Antiochus's self-sacrificial love turns in Ferrand's narrative into a parody, especially as the lover misguidedly quotes elegiac poetry as evidence his father will agree to his marriage plans (Ferrand 1623, 273). ${ }^{24}$

The beating pulse, like breathing, establishes a body's natural rhythm, a rhythm that is disrupted in cases of love melancholy. The disruption of that rhythm is for the physician to observe, record, and diagnose by experimenting with and producing knowledge at the expense of the lover but for the lover at the same time. The lover both performs and 
is performed by the symptoms, the sigh and pulse both ridiculed and taken seriously. Trying to account for the body's disrupted rhythms, the physician creates a narrative of displacement that works on multiple levels. First, the love object allows no space in the heart for the air to circulate; love has displaced breath. Second, as the lover's sighs are evidence of an extra, a double breath to account for the missed opportunity to breathe regularly, the displaced air returns forcefully to the body, throwing it out of tune. Third, sighing becomes synonymous with verse recital: the body vents its love through poetry, regaining the balance and rhythm (poetic in this case) that it has lost in material terms. Finally, the physician identifies the melancholic body's isolation yet isolates it further by keeping a perceived objective distance from it. Observing inevitably includes a process of distancing and narrativizing that keeps the writers separate from the condition they describe.

Yet the external point of view at times collapses, bringing ill and healthy bodies into conversation and conspiration with one another. This is most obvious in poetry, as in Herbert's case, where speaker, poet, and reader meet in the brackets, in an example of conspiration that works not only vertically, but, as Peter Adey claims, horizontally. ${ }^{25}$ The coordinates of breath, however, do not only have two dimensions but expand to map a depth of transhistorical and transliterary points of reference. Conspiration in this respect is not only between bodies or between bodies and the cosmos, but also between bodies and texts. This level of interdependent breathing finds its way through poetry in Burton's text too: the quick, short, and successive verses suggest the tempo of the writing changes to capture the intensity and multivocality of love melancholy. The lover's rhythm supersedes and encompasses the author's and the two meet not in brackets as such but in printed demarcations that introduce voices other than the speaker's. Similarly, Ferrand's tribute to Sappho and his creative reimagining of the Antiochus and Stratonice story expose a playful and inventive tendency to be part of the passions he records. The treatise's intertextual references make for a fluid and interpersonal experience that transcends the physician-patient binary. In the above cases, the emotional body that suffers is displaced as its air is displaced, but the form in which this body is written complicates pathological readings. The authorial subjectivity of the observer in the above cases is shaped in tandem with the patient's emotional load.

Breath, therefore, is not just a useful reflex mechanism allowing the body to restore its balance. It facilitates the move from the aesthetic 
realm into which love transposes the patient back to the natural rhythms of existence. Yet in doing so it complicates this binary and the broader binary to which the performative sighing versus healthy body points: that of objective measurement and knowledge and subjective experience. Relating to the lover, but also to the author, relating to medicine, but also to poetry, the representation of breath in the texts studied in this essay destabilizes the role of the presumably external, disengaged, and disinterested witness. It shows points of connection and alternative interpretations that challenge the 'rift' that Havi Carel describes in the clinic, and specifically in respiratory medicine: 'there is a substantial difference between the objective domain of physical bodies, disease, and physiological dysfunction, and the subjective experience of it. There is a gap between symptom and experience, and between physiological disease and how it is lived by people'. ${ }^{26}$ This gap is evident in the observer-patient cases of Herbert, Burton, and Ferrand, where bodies in love and their breathing are reduced to their diagnostic symptoms. This essay has tried to show that if we expand our understanding of disrupted rhythms and patterns from the body outwards towards observers and the language they use to record disruption we might approach the phenomenological perspective Carel envisions for clinical practice in a new light. Carel's call for phenomenology in the clinic invites health professionals to consider first-person subjective accounts of breathlessness so they can build on the patient's 'insider' perspective. ${ }^{27}$ The poetic and non-discipline-specific vocabulary of early modern treatises on the passions may suggest ways in which the language physicians use might be (consciously or not) informed by the experience of the patients, allowing for a deeper level of empathy and insight. ${ }^{28}$ Seen as producing and re-enacting an entangled mess of bodies and stories, emotional breathing can cast either patient or observer as the subject of Du Laurens' claim that in illness, 'he is there where indeede he is not'.

Acknowledgements The author would like to thank the editors of the collection for their generosity, insight, and patience, and the TRU3910 Feeling Bodies seminar groups (University of Exeter, Penryn, Spring 2019) for their inspiring and provocative readings of emotions in early modern literature and culture. 


\section{Notes}

1. 'Breathing Exercise for Stress', NHS Moodzone (2018) https:// www.nhs.uk/conditions/stress-anxiety-depression/ways-relieve-stress/\# [accessed 12th April 2019].

2. 'ReConnect2Life-Creating Skills for the Future: Deep Breathing Exercise', NHS Torbay and South Devon (2019) https://www.torbay andsouthdevon.nhs.uk/services/pain-service/reconnect2life/creatingskills-for-the-future/learning-relaxation-skills/deep-breathing-exercise/ [accessed 12th April 2019].

3. George Herbert, 'Love Unknown', in The Works of George Herbert, ed. by F. E. Hutchinson (Oxford: Clarendon, 1941), 129-31. All references to 'Love Unknown' are to this edition and are listed parenthetically and by line number in the text.

4. Richard Strier, Love Known: Theology and Experience in George Herbert's Poetry (Chicago: Chicago University Press, 1983), 164.

5. Strier, Love Known, 163. On the emotional rollercoaster of Protestant experience, see also Alec Ryrie, Being Protestant in Reformation Britain (Oxford: Oxford University Press, 2013), 17-98.

6. On Herbert's melancholy see Anne-Marie Miller Blaise, 'George Herbert's Distemper: An Honest Shepherd's Remedy for Melancholy', in John Donne and the Metaphysical Poets, ed. by Harold Bloom (New York: Bloom's Literary Criticism, 2010), 142.

7. Helen Wilcox, George Herbert: 100 Poems (Cambridge: Cambridge University Press, 2016), x.

8. Angela Balla, 'Baconian Investigation and Spiritual Standing in Herbert's The Temple', George Herbert Journal 34/1 (2010): 65 https://doi.org/ 10.1353 /ghj.2010.0001.

9. Richard Meek and Erin Sullivan, eds, The Renaissance of Emotion (Manchester: Manchester University Press, 2015), 3. Meek and Sullivan usefully summarize key studies in fn. 3 of the cited page.

10. For quick reference to the wealth of perspectives, see the contents page in Susan Broomhall, ed., Early Modern Emotions: An Introduction (London: Routledge, 2017).

11. Predominantly Gail Kern Paster, Humoring the Body: Emotions and the Shakespearean Stage (Chicago: The University of Chicago Press, 2004); Luce Irigaray, The Forgetting of Air in Martin Heidegger (London: Athlone Press, 1999).

12. See Carla Mazzio, 'The History of Air: Hamlet and the Trouble with Instruments', Shakespeare \& Science 26/1 (2009): 153-96 https://doi. org/10.1353/scr.0.0039. Notable exceptions that take into account the poetics of breath and its rhetorical force include Gina Bloom, Voice in Motion: Staging Gender, Shaping Sound in Early Modern England 
(Philadelphia: University of Pennsylvania Press, 2007), Leah Knight, Reading Green in Early Modern England (London: Routledge, 2014), and Rebecca Totaro, "Revolving This Will Teach Thee How to Curse": Lessons in Sublunary Exhalation', in Rhetorics of Bodily Disease and Health in Medieval and Early Modern England, ed. Jennifer C. Vaught (New York: Routledge, 2010): 135-51.

13. I am referring to these texts as treatises of the passions rather than emotions here, following their titles and early modern terminology. Nevertheless, the essay does not adopt rigid distinctions between these terms. I agree with Thomas Dixon that 'there are important differences in nuance to all these terms [he cites emotions, passions, affections, or sentiments] that should not be effaced', but I take issue with curtailing the use of these terms. In reference to emotion specifically, Dixon argues that 'the word "emotions" is currently used too liberally by historians of psychology and its reference needs to be narrowed'; he suggests any application of the term to pre-nineteenth-century contexts is anachronistic [see Thomas Dixon, From Passions to Emotions: The Creation of a Secular Psychological Category (Cambridge: Cambridge University Press, 2003), 11-12]. Scholars of emotions in the early modern period, however, counter-argue that 'during the seventeenth century, it [emotions] is a word whose meaning is in flux' [see David Thorley, 'Towards a History of Emotion, 1562-1660', The Seventeenth Century 28/1 (2013): 15, https://doi.org/ $10.1080 / 0268117 X .2012 .757943$ ] and acknowledge there is always 'a certain amount of arbitrariness built into the project of choosing which current terms to use to describe the past' and 'the term "emotions" begins to look quite attractive as an option that covers the variety of equally ambiguous terms in these texts' [see Kirk Essary, 'Passions, Affections, or Emotions? On the Ambiguity of $16^{\text {th }}$-Century Terminology', Emotion Review 9/4 (2017), 368 https://doi.org/10.1177/175407391 $6679007]$.

14. A full discussion of the passion of lovesickness and its appeal to the early modern medical and literary imagination is beyond the scope of my analysis in this essay. For a firm grounding in its cultural and philosophical contexts throughout the centuries, see the Introduction by Beecher and Ciavolella in their edition of Ferrand's treatise, Of Lovesickness. For lovesickness in an early modern English context see Lesel Dawson, Lovesickness and Gender in Early Modern English Literature (Oxford: Oxford University Press, 2008).

15. Robert Burton, The Anatomy of Melancholy, ed. by Thomas C. Faulkner, Nicolas K. Kiessling, and Rhonda L. Blair, with commentary by J. B. Bamborough with Martin Dodsworth, 6 vols (Oxford: Clarendon Press, 1989-2000), vol. 1, 139. All references to Burton are to this edition and 
are cited parenthetically in the text, with volume number followed by page numbers.

16. Timothy Bright, A Treatise of Melancholie (London: Printed by Thomas Vautrollier, 1586), 160. For a wider discussion of sighing and the regulation of breath in the early modern period see Naya Tsentourou, 'Wasting Breath in Hamlet', in Reading Breath in Literature, by Arthur Rose, et al., (Palgrave, 2018): 39-62.

17. André Du Laurens, A Discourse of the Preservation of the Sight; of Melancholike Diseases; of Rheumes and of Old Age, trans. by Richard Surphlet (London: Imprinted by Felix Kingston, 1599), 118.

18. Jacques Ferrand, Erotomania, or a Treatise Discoursing of the Essence, Causes, Symptomes, Prognosticks, and Cure of Love, trans. by Edmund Chilmead (Oxford: Printed by L. Lichfield, 1640). See also Ferrand, $A$ Treatise on Lovesickness, ed. and trans. by Donald A. Beecher and Massimo Ciavolella (New York: Syracuse University Press, 1990). Beecher and Ciavolella's translation is based on the second edition of the treatise, published in French in 1623. The first edition, significantly shorter, appeared in 1610. For a selection of potential sources, the editors have identified for Ferrand's examination of sighing in lovers, including Du Laurens, see pages $452-53$, fn. 4 . Subsequent references to Ferrand's treatise are cited parenthetically in the text, by year of edition and page numbers.

19. Drew Daniel, The Melancholy Assemblage: Affect and Epistemology in the English Renaissance (New York: Fordham University Press, 2013), 161. On Burton's style see also Mary Ann Lund, Melancholy, Medicine and Religion in Early Modern England: Reading the Anatomy of Melancholy (Cambridge: Cambridge University Press, 2010).

20. Editors Beecher and Ciavollela suggest that, although Burton references Ferrand in the fourth edition of the Anatomy (1632), no direct influence can be established. 'After Ferrand, only Burton had the energy to peruse the vast documentation traditionally attached to the topos [of amor hereos], but for reasons different to Ferrand's' (Ferrand 1623, 16).

21. For a concise summary of the story's influence see Ferrand 1623, 48-51. For the story's wider historical context and its place in medical tradition see Daniel Ogden, The Legend of Seleucus: Kingship, Narrative and Mythmaking in the Ancient World (Cambridge: Cambridge University Press, 2017), ch. 5.

22. Du Laurens, A Discourse, 118-19.

23. Jean-William Fitting, 'From Breathing to Respiration', Respiration 89 (2015), 82-87 https://doi.org/10.1159/000369474.

24. The line is from Propertius's Elegies, Bk 1, Elegy 5: 'Love knows no pedigrees, will cede to no old portraits'. It is spoken by Propertius to Gallus warning him against courting Cynthia, the poet's own love object. Propertius, Elegies, ed. and trans. by G. P. Goold (Loeb Classical Library 
18. Cambridge, MA: Harvard University Press, 1990), 51-52 https:// doi.org/10.4159/dlcl.propertius-elegies.

25. For my understanding of conspiration I am very much indebted to Phillip Horky's presentation, "Our Common Breath: $\sigma v \mu \pi v o i \alpha$ from Early Christianity to Neopythagoreanism". The Life of Breath: History, Texts, Contexts Conference, 10-12 July 2018, Durham University. Peter Adey made the point about horizontal and vertical breathing as part of his closing presentation at the same conference.

26. Havi Carel, 'Breathlessness: The Rift between Objective Measurement and Subjective Experience', Lancet Respiratory Medicine 6/5 (2018), 332 https://doi.org/10.1016/S2213-2600(18)30106-1.

27. Havi Carel, 'Invisible Suffering: The Experience of Breathlessness', in Atmospheres of Breathing: The Respiratory Questions of Philosophy, ed. by Lenart Škof and Petri Berndtson (New York: SUNY Press, 2018), 241.

28. In this light, a literary work like Paul Kalanithi's When Breath Becomes Air (London: Bodley Head, 2016) can be seen as a modern-day equivalent to the aspects of Burton and Ferrand's work on which this essay has focused.

\section{SELECTED Bibliography}

Carel, Havi. 2018. Invisible Suffering: The Experience of Breathlessness. In Atmospheres of Breathing: The Respiratory Questions of Philosophy, ed. Lenart Škof and Petri Berndtson, 233-46. New York: SUNY Press.

Dawson, Lesel. 2008. Lovesickness and Gender in Early Modern English Literature. Oxford: Oxford University Press.

Kalanithi, Paul. 2016. When Breath Becomes Air. London: Bodley Head.

Lund, Mary Ann. 2010. Melancholy, Medicine and Religion in Early Modern England: Reading the Anatomy of Melancholy. Cambridge: Cambridge University Press.

Meek, Richard, and Erin Sullivan, eds 2015. The Renaissance of Emotion. Manchester: Manchester University Press.

Paster, Gail Kern. 2004. Humoring the Body: Emotions and the Shakespearean Stage. Chicago: The University of Chicago Press. 
Open Access This chapter is licensed under the terms of the Creative Commons Attribution 4.0 International License (http://creativecommons.org/licenses/ by $/ 4.0 /$ ), which permits use, sharing, adaptation, distribution and reproduction in any medium or format, as long as you give appropriate credit to the original author(s) and the source, provide a link to the Creative Commons license and indicate if changes were made.

The images or other third party material in this chapter are included in the chapter's Creative Commons license, unless indicated otherwise in a credit line to the material. If material is not included in the chapter's Creative Commons license and your intended use is not permitted by statutory regulation or exceeds the permitted use, you will need to obtain permission directly from the copyright holder.

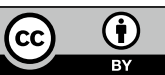

